Supplement of Atmos. Chem. Phys., 16, 6355-6363, 2016

http://www.atmos-chem-phys.net/16/6355/2016/

doi:10.5194/acp-16-6355-2016-supplement

(C) Author(s) 2016. CC Attribution 3.0 License.

(c) (i)

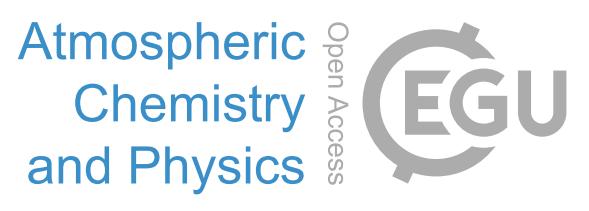

Supplement of

\title{
Formation of reactive nitrogen oxides from urban grime photochemistry
}

Alyson M. Baergen and D. James Donaldson

Correspondence to: D. James Donaldson (jdonalds@chem.utoronto.ca)

The copyright of individual parts of the supplement might differ from the CC-BY 3.0 licence. 


\section{S1. Characterization of Experimental Chamber}

Known amounts of $\mathrm{NO}_{2}$ in $\mathrm{N}_{2}$ were flowed through the sample illumination chamber and IBBCEAS cell in order to characterize the observed HONO for different experimental variables. The current set up facilitates an efficient $\mathrm{NO}_{2}$ surface hydrolysis, forming HONO. Results are shown in Fig. S1 for both dark and light experiments as a function of $\mathrm{RH}$. An input $\mathrm{NO}_{2}$ concentration of $6.0 \mathrm{ppm}$, based on the reported value from the supplier (Linde), was further diluted with $\mathrm{N}_{2}$ using needle valves and mass flow meters with uncertainties of $\pm 0.5 \mathrm{~mL} / \mathrm{min}$ to a concentration of $(4.76 \pm 2.4) \times 10^{12}$ molecules $/ \mathrm{cm}^{3}$. The figure displays the measured $\mathrm{NO}_{2}$ and $\mathrm{HONO}$ concentrations detected by the IBBCEAS as a function of RH. The calculated total concentration measured from the sum of $\mathrm{NO}_{2}$ and twice the $\mathrm{HONO}$, following the mass balance implied by Equation 1, was $(3.6 \pm 0.3) \times 10^{12}$ molecules $/ \mathrm{cm}^{3}$ which is within error of that calculated from the $\mathrm{NO}_{2}$ concentration coming from the cylinder reported above. This suggests that this technique can quantify the total concentration of $\mathrm{NO}_{2}+\mathrm{HONO}$ here, though cannot accurately speciate $\mathrm{NO}_{2}$ and $\mathrm{HONO}$. Fig. S1b shows that the total concentration decreases upon illumination, due to the photolysis of $\mathrm{NO}_{2}$ and HONO. The HONO concentration measured is independent of relative humidity within the $30 \%$ coefficient of variability measured between samples. $\mathrm{No} \mathrm{NO}_{2}$ was detected. This shows that the $\mathrm{NO}_{2}$ to $\mathrm{HONO}$ conversion is complete within error, and that there is no significant impact on the IBBCEAS $\mathrm{NO}_{2}+\mathrm{HONO}$ response as a function of relative humidity. We note that if the photochemical product distribution between $\mathrm{NO}_{2}$ and $\mathrm{HONO}$ changes with relative humidity, this will impact the total amount measured, because it takes two $\mathrm{NO}_{2}$ molecules to make one $\mathrm{HONO}$ molecule. Thus a change from only $\mathrm{NO}_{2}$ production to only HONO production would appear as a $50 \%$ change in the total amount detected as HONO. However, the changes measured as a function of RH are larger than can be explained by this mechanism.

Thus the total product concentrations from grime photochemistry may be safely compared as a function of RH. No values are shown below 13\% in Fig. 3 and Fig. S1 because the RH meter is not sensitive below $10 \%$ and thus we cannot accurately report RH values. As well, when $\mathrm{N}_{2}$ is flowed through the chamber without humidification, the total signal for $\mathrm{NO}_{2}$ and $\mathrm{HONO}$ does not reach a plateau even after one hour. This indicates that the $\mathrm{NO}_{2}$ is being irreversibly lost to the walls, likely forming complexes with the metal (Nishino and Finlayson-Pitts, 2012). 

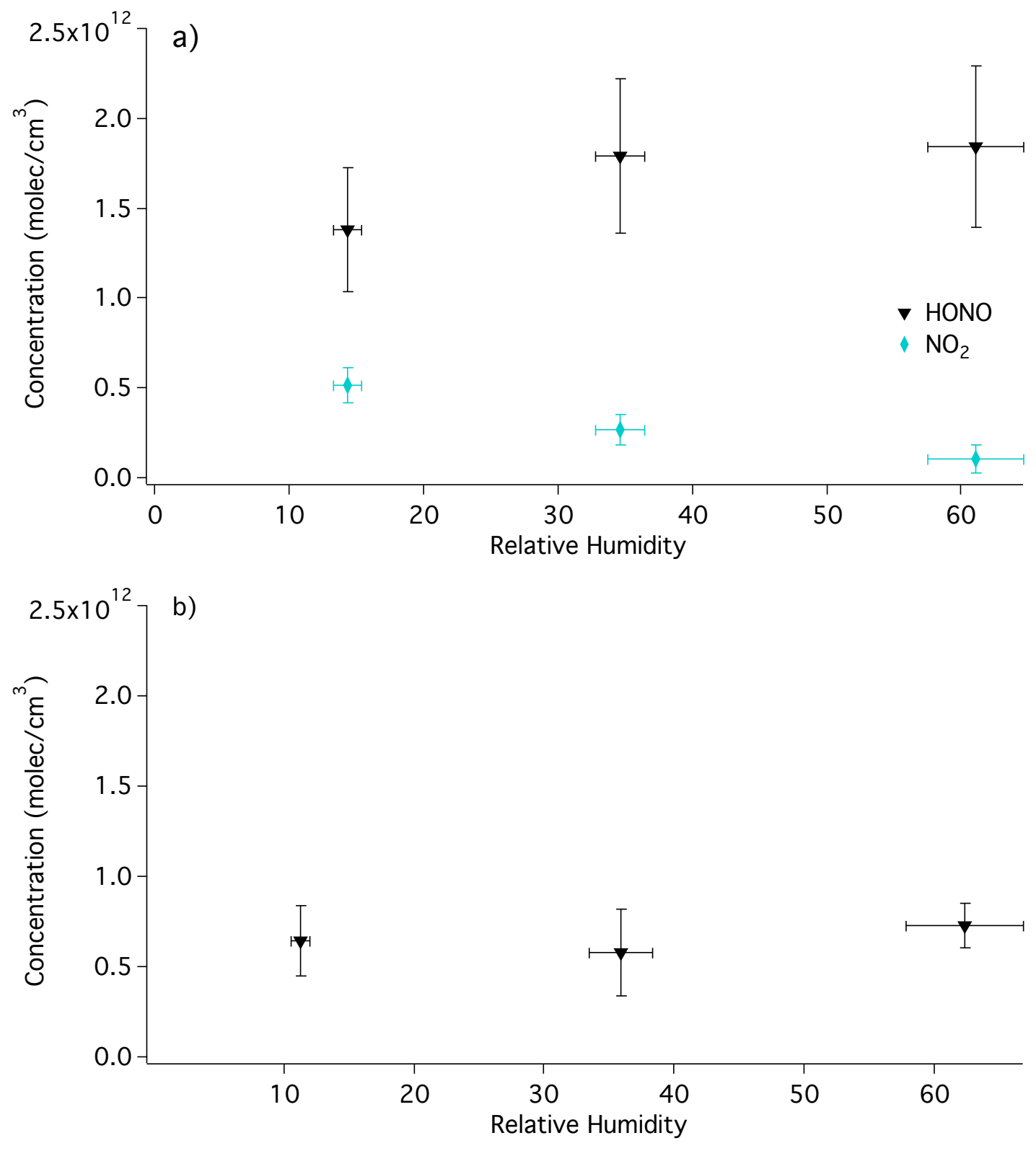

Figure S1: Concentrations of $\mathrm{HONO}$ and $\mathrm{NO}_{2}$ for $\mathrm{NO}_{2}$ flowed through the chamber and IBBCEAS cell as a function of RH a) in the dark and b) in the light. Only HONO concentrations are shown in Fig. S1b because no $\mathrm{NO}_{2}$ was detected. The error bars represent one standard deviation of the average of three experiments.

Table S1: Inorganic ion content of grime used for photochemistry experiments $(n=3)$

\begin{tabular}{|c|c|c|c|c|c|c|c|}
\hline & Chloride & Nitrate & Sulfate & Sodium & Potassium & Magnesium & Calcium \\
\hline $\begin{array}{c}\text { Concentration } \\
\left(\mu \mathrm{g} / \mathrm{cm}^{2}\right)\end{array}$ & 4.8 & 0.73 & 4.27 & 4.9 & 0.34 & 1.27 & 2.11 \\
\hline $\begin{array}{c}\text { Standard } \\
\text { Deviation }\end{array}$ & 0.1 & 0.01 & 0.04 & 0.2 & 0.01 & 0.05 & 0.05 \\
\hline
\end{tabular}




\section{References}

Nishino, N. and Finlayson-Pitts, B. J.: Thermal and photochemical reactions of $\mathrm{NO}_{2}$ on chromium(III) oxide surfaces at atmospheric pressure, Phys Chem Chem Phys, 14(45), 15840-15848, doi:10.1039/c2cp42292a, 2012. 